\title{
Relationship between lonic Perturbations and Electrophysiologic Changes in a Canine Purkinje Fiber Model of Ischemia and Reperfusion
}

\author{
Raymond Yee, Kathleen K. Brown, D. Eric Bolster, and Harold C. Strauss \\ Departments of Medicine and Pharmacology, Duke University Medical Center, Durham, North Carolina 27710
}

\begin{abstract}
Standard and ion-sensitive microelectrodes were used to identify the basis of electrophysiologic changes that occur in canine cardiac Purkinje fibers superfused with "ischemic" solution (40 $\mathrm{min}$ ) and then returned to standard Tyrode's solution. Maximum diastolic potential ( $\left.E_{\text {MDP }}\right)$ decreased ( $-92.6 \pm 2.4$ to $-86.0 \pm 4.0 \mathrm{mV} ; n=19 ; P<0.001)$ during exposure to "ischemia," and after reperfusion, rapidly hyperpolarized to $-90.0 \pm 4.7(2 \mathrm{~min})$ and then depolarized to $-47.0 \pm 7.5 \mathrm{mV}$ (10 min; $P<0.001)$. No significant change in intracellular $K$ activity $\left(\alpha_{\mathrm{K}}^{\mathrm{i}}\right)$ was noted throughout. Extracellular $\mathrm{K}$ activity $\left(\alpha_{\mathrm{K}}^{\mathrm{e}}\right)$ changed only during reperfusion, reaching a nadir at $5 \mathrm{~min}$ (3.5 \pm 0.4 to $2.6 \pm 0.5 \mathrm{mM}, P<0.03$ ), and thus can not account for the decrease in $E_{\mathrm{MDP}}$ during reperfusion. Mean $\alpha_{\mathrm{Na}}^{i}$ increased $(8.7 \pm 1.3$ to $10.9 \pm 1.9 \mathrm{mM} ; n=10 ; P<0.01)$ during ischemia, but rapidly declined during reperfusion to $5.1 \pm 2.2$ mM (10 min; $P<0.01$ ). Exposure to acetylstrophanthidin $\left(4-5 \times 10^{-7} \mathrm{M}\right)$ during the final $10 \mathrm{~min}$ of ischemia increased $\alpha_{\mathrm{Na}}^{i}$ to $19.9 \pm 3.8 \mathrm{mM}(n=5)$, which was unchanged at $5 \mathrm{~min}$ of reperfusion. This suggests that $\mathrm{Na}-\mathrm{K}$ pump inhibition during ischemia was minimal and that the pump was stimulated early during reperfusion, accounting for the initial transient hyperpolarization. Resting tension did not change significantly during exposure to ischemia; however, return to control Tyrode's solution caused a marked rise to $11.3 \pm 9.9 \mathrm{mg} / \mathrm{mm}^{2}(n=13, P$ $<0.001)$. This is consistent with a calcium overload state during reperfusion. The depolarization seen during reperfusion may result from activation of a Ca-activated, nonselective cation channel or enhanced electrogenic $\mathrm{Na} / \mathrm{Ca}$ exchange.
\end{abstract}

\section{Introduction}

The electrophysiologic and metabolic consequences of myocardial ischemia and postischemic reperfusion injury have been the subject of intensive investigation (1-5), yet our understanding of the ionic perturbations resulting from these pathologic states is limited by the techniques available to measure ionic changes during interruption of tissue perfusion. Measurements of total ionic content do not truly reflect changes in the thermodynamically active fraction of intracellular ions, since redistribution of ions between various subcompartments of a cell may occur. Yet measures of intracellu-

Address reprint requests to Dr. Strauss, Department of Medicine, Box 3845, Duke University Medical Center, Durham, NC 27710.

Received for publication 18 May 1987 and in revised form $24 \mathrm{Feb}$ ruary 1988.

J. Clin. Invest.

(c) The American Society for Clinical Investigation, Inc.

0021-9738/88/07/0225/09 \$2.00

Volume 82, July 1988, 225-233 lar ion activity using methods such as ion-selective microelectrodes are difficult to apply to experimental models of ischemia. Furthermore, heterogeneity in regional myocardial blood flow and in the degree of extracellular $\mathrm{K}^{+}$accumulation between the center and edge of the ischemic zone occurs following coronary artery ligation (6), potentially limiting the evaluation of underlying mechanisms of in vivo models of myocardial ischemia. To circumvent these limitations, some investigators have chosen to examine individual components of ischemia, allowing for a more meaningful temporal analysis of the underlying events.

The consequences of tissue underperfusion are well known. They include depletion of vital metabolic substrates such as glucose, $\mathrm{O}_{2}$, and high-energy phosphates, and accumulation of metabolites such as lactate, inorganic phosphate $\left(\mathrm{P}_{\mathrm{i}}\right), \mathrm{ADP}, \mathrm{H}^{+}$within the cell, and $\mathrm{K}^{+}$within the extracellular space. In an effort to characterize and measure the ionic, metabolic, or hemodynamic changes, investigators have employed experimental models involving hypoxia, acidosis, hyperkalemia, and glucose depletion, alone or in combination.

Ferrier et al. $(7,8)$ recently described a model of ischemia and reperfusion wherein canine false tendons were exposed to hypoxia, lactic acidosis, and glucose-free conditions. "Ischemic conditions" caused a depolarization. Upon "reperfusion," preparations demonstrated transient hyperpolarization, progressive depolarization to inexcitability, and final repolarization to control values. The depolarization phase was accompanied by oscillatory afterpotentials, which initiated extrasystoles. Recent experiments from our own and other laboratories suggest that this model might also be relevant for arrhythmias occurring during reperfusion after brief periods of occlusion. Although initially one might presuppose that disturbances in $\mathrm{K}$-channel permeability and/or $\mathrm{Na}-\mathrm{K}$ pump activity underlie many of the electrophysiologic changes, it is likely that disturbances of other ionic permeation pathways as well as other membrane transporters also underlie the electrophysiologic abnormalities seen in both phases of the model. As a necessary first step in identifying the potential scope of the abnormalities, we set out to characterize in detail changes in intracellular and extracellular cation $\left(\mathrm{Na}^{+}, \mathrm{H}^{+}, \mathrm{K}^{+}\right)$activity and to correlate these changes with the electrophysiologic and mechanical changes observed in this ischemia and reperfusion model. Such information should help elucidate the basis of the electrophysiologic changes that occur during both ischemia and reperfusion.

\section{Methods}

Tissue preparations. Adult mongrel dogs weighing $15-25 \mathrm{~kg}$ were anesthetized with sodium pentobarbital $(30 \mathrm{mg} / \mathrm{kg})$ intravenously. Hearts were exposed through a left thoracotomy, rapidly excised, and immersed in iced Tyrode's solution $\left(4^{\circ} \mathrm{C}\right)$ containing K-glutamate (16 $\mathrm{mM})$. Purkinje fibers from both left and right ventricles were dissected 
Table I. Composition of Solutions Used to Superfuse Purkinje Fibers

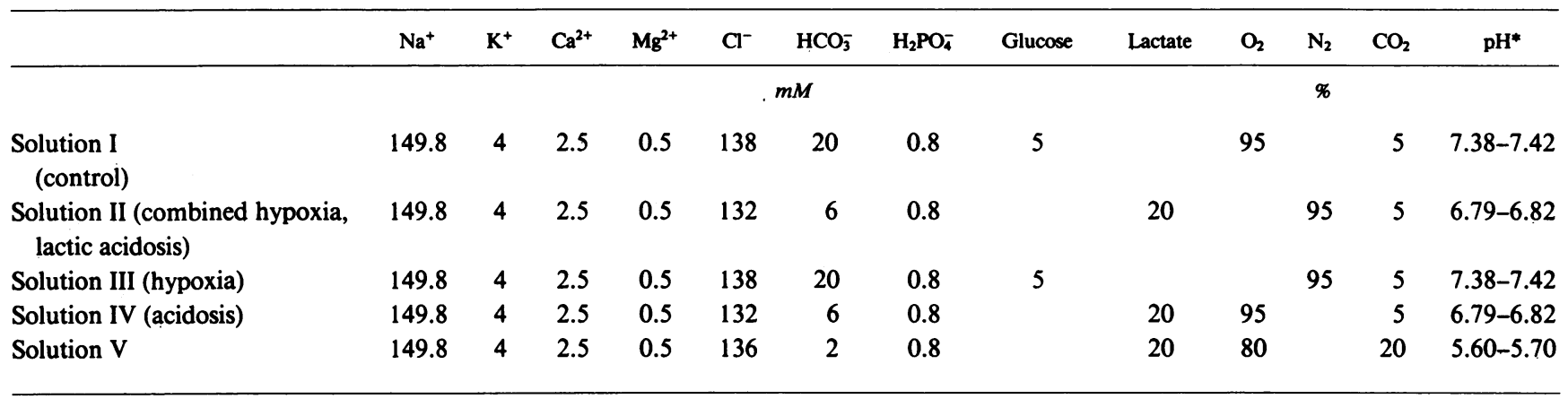

* Data expressed as range of values.

and transferred to a petri dish containing regular Tyrode's solution $\left(22^{\circ} \mathrm{C}\right)$.

Purkinje fibers of $<1 \mathrm{~mm}$ transverse diameter were placed into a rapid flow tissue bath $(0.7 \mathrm{ml})$ and superfused with regular Tyrode's solution (solution $I$ in Table I), maintaining a bath temperature of $37 \pm 0.5^{\circ} \mathrm{C}$ and a solution flow rate of $10-12 \mathrm{ml} / \mathrm{min}$. A bipolar silver wire electrode was applied to the proximal end of the fiber to stimulate it at $1 \mathrm{~Hz}$. In most Purkinje fibers, a 5.0 silk ligature was tied to the distal end and connected to a force transducer (model 403, Cambridge Technologies, Inc., Cambridge, MA). Fibers were stretched by $5-10 \%$ and allowed to equilibrate.

Solutions. Five different electrolyte solutions were utilized in these experiments (Table I). Solution I was bubbled with a gas mixture of $95 \% \mathrm{O}_{2} / 5 \% \mathrm{CO}_{2}$ to attain a final pH of 7.38-7.42. Solution II was used to expose preparations to conditions similar to those present during ischemia (hypoxia, lactic acidosis, glucose depletion, $\mathrm{pH}$ 6.79-6.82). The solution reservoir containing solution II was equipped with a one-way valve to exclude entry of $\mathrm{O}_{2}$ into the container, allowing us to obtain $\mathrm{PO}_{2}$ values of $<15 \mathrm{mmHg}$ in the container and $<30 \mathrm{mmHg}$ at the level of the tissue bath. For those experiments requiring exposure of preparations to hypoxia alone, solution III was bubbled with $95 \%$ $\mathrm{N}_{2} / 5 \% \mathrm{CO}_{2}$ (pH 7.38-7.42). For experiments involving exposure of preparations to mild metabolic acidosis alone (pH 6.79-6.82), the solution was modified to contain $6 \mathrm{mM} \mathrm{NaHCO}_{3}$ and $20 \mathrm{mM}$ lactate (solution IV). Solution V was used to achieve extreme intracellular acidosis in a small series of experiments by exposing preparations to a $\mathrm{pH}_{0}$ of $5.60-5.70$.

A pH/gas analyzer (model 113, Instrumentation Laboratory, Inc., Boston, MA) was used to measure the $\mathrm{PO}_{2}$ and $\mathrm{pH}$ of all solutions.

Microelectrodes. Conventional microelectrodes for recording transmembrane potential were constructed from single-barreled borosilicate glass capillary tubes ( $1.2 \mathrm{~mm}$ o.d., $0.9 \mathrm{~mm}$ i.d.) heat-drawn to a resistance of 15-20 M , backfilled with $3 \mathrm{M} \mathrm{KCl}$, and beveled to a predetermined resistance. Ion-selective microelectrodes for measuring intracellular ionic activity of $\mathrm{Na}^{+}\left(\alpha_{\mathrm{Na}}^{\mathrm{i}}\right), \mathrm{H}^{+}\left(\mathrm{pH}_{\mathrm{i}}\right)$, or $\mathrm{K}^{+}\left(\alpha_{\mathrm{K}}^{\mathrm{i}}\right)$ were constructed in a manner similar to that of other investigators $(9-12)$. Briefly, heat-drawn, single-barreled glass capillary tubes were silanized using trimethylsilyldiethylamine (Sigma Chemical Co., St. Louis, MO) in a $100 \% \mathrm{~N}_{2}$ environment and $150^{\circ} \mathrm{C}$ vacuum oven. Microelectrode blanks were backfilled under pressure with the appropriate electrolyte solution $\left(\mathrm{Na}^{+}, 300 \mathrm{mM} \mathrm{NaCl} ; \mathrm{H}^{+}, 40 \mathrm{mM} \mathrm{NaH}_{2} \mathrm{PO}_{4}, 15 \mathrm{mM} \mathrm{NaCl}, 23\right.$ $\mathrm{mM} \mathrm{NaOH}, \mathrm{pH} 7.0 ; \mathrm{K}^{+}, 500 \mathrm{mM} \mathrm{KCl}$ ), beveled to a predetermined resistance, and filled with the appropriate ion-exchange resin $\left(\mathrm{Na}^{+}\right.$, ETH 227; $\mathrm{H}^{+}$, N-TDDA; $\mathrm{K}^{+}$, Corning 477317 ) by negative pressure. Voltage recorded from conventional and ion-selective microelectrodes, the difference signal, and tension were monitored simultaneously on an oscilloscope and recorded on a Gould 2400S chart recorder (Gould Instruments, Inc., Cleveland, $\mathrm{OH}$ ).

Double-barreled $\mathrm{K}^{+}$-selective microelectrodes were silanized in a manner identical to that of single-barreled electrodes. The reference barrel was pressure-filled with $\mathrm{NaCl}(300 \mathrm{mM})$, while the ion-selective barrel was filled with the same solution and resin as the single-barreled microelectrodes. For measurement of extracellular space $\mathrm{K}^{+}\left(\alpha_{\mathrm{K}}^{\mathrm{e}}\right)$, the double-barreled microelectrode was advanced into and through the first cell encountered into the extracellular space. Time was allowed for elevated $\alpha_{\mathrm{K}}^{\mathrm{e}}$ values to subside toward bath levels. Proper positioning of the electrode was confirmed by observing the accumulation and depletion of $\alpha_{\mathrm{K}}^{\mathrm{e}}$ after transient stimulation of the preparation at $2.5 \mathrm{~Hz}$ as well as brief superfusion of the fiber with Tyrode's solution containing $\mathrm{KCl}(8 \mathrm{mM})(13,14)$.

Calibration was performed for each microelectrode at $37^{\circ} \mathrm{C}$ before and after use in each experiment using seven mixed ion solutions with constant total ionic strength $(150 \mathrm{mM})$ and five pure ion solutions as described by Lee (15). The preparation of mixed calibrating solutions was adjusted to select concentrations of the principal ion that fell above and below the concentration range of interest. The same reference ground was used for the calibration procedure as for the experiment. The slope was calculated from single electrolyte solutions containing the primary ion and selectivity coefficient from comparison of voltages in pure ion and mixed ion solutions. A single activity coefficient value of 0.75 was assumed for $\mathrm{K}^{+}$and $\mathrm{Na}^{+}$in mixed solutions (15). A calibration curve was obtained which allowed the difference voltage obtained during experiments to be converted to intracellular ion activity. Acceptable slope responses in millivolts per $\log$ ion activity and selectivity coefficient values for the $\mathrm{Na}^{+}, \mathrm{H}^{+}$, and $\mathrm{K}^{+}$ion-selective microelectrodes were $>51, K_{\mathrm{KNa}}<0.02 ;>57, K_{\mathrm{HK}}<0.0001,>54, K_{\mathrm{KNa}}$ $<0.01)$, respectively.

Experimental protocol. Purkinje fibers were allowed to equilibrate in the tissue bath and were superfused with regular Tyrode's solution

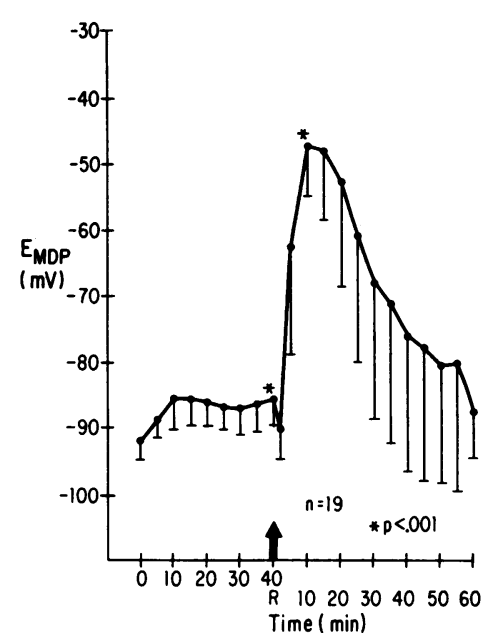

Figure 1. Time course of maximum diastolic potential $\left(E_{\mathrm{MDP}}\right)$ during and after 40-min exposure to a combination of hypoxia, glucose depletion, and lactic acidosis (solution II). Data points at 5-min intervals represent mean \pm standard deviation in 19 experiments. Arrow in this and subsequent figures indicates return to control Tyrode's solution (solution I). Asterisk in this and subsequent figures denotes values which are significantly different from control values. 


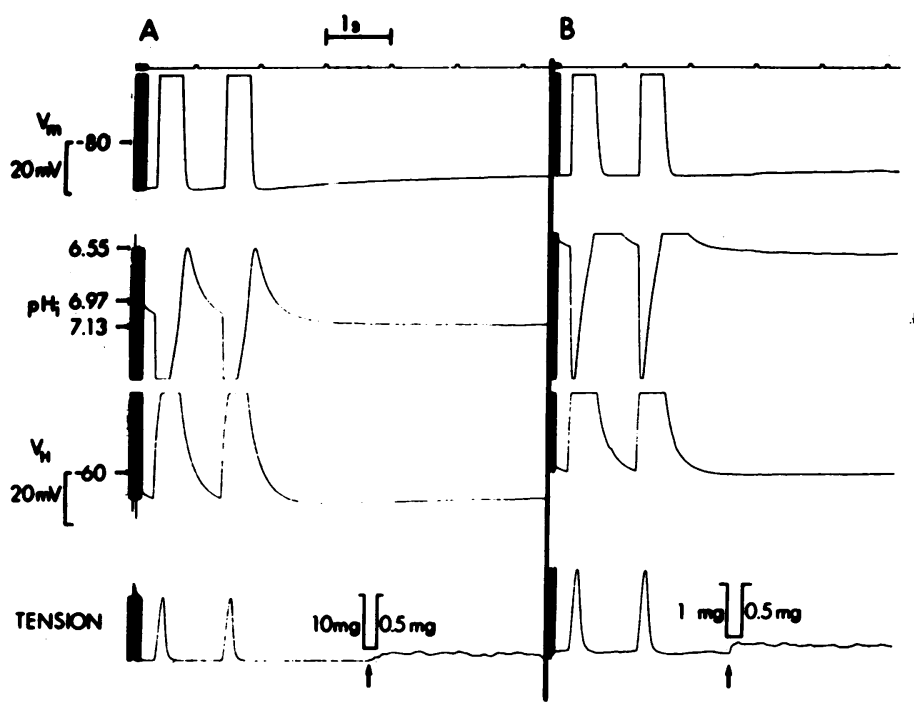

Figure 2. Simultaneous recording of membrane potential and $\mathrm{pH}_{\mathrm{i}}$ along with the difference signal, and tension at selected time intervals during exposure to control Tyrode's solution $(A)$ at the end of $\mathbf{4 0}$ min of exposure to solution II $(B) 10$ min after reexposure to control

for at least $1 \mathrm{~h}$ until tension trace recordings had stabilized. Fibers were then superfused with Tyrode's solution II for $\mathbf{4 0} \mathrm{min}$, followed by return to Tyrode's solution I for up to $60 \mathrm{~min}$. In addition to tension recordings, Purkinje fibers were simultaneously impaled with one conventional microelectrode and one ion-selective microelectrode placed less than one space constant $(<2 \mathrm{~mm})$ apart. Only data from those experiments in which Purkinje fibers responded to the return to solution I by exhibiting a depolarization of maximum diastolic potential (MDP) to $<-70 \mathrm{mV}$ and loss of excitability were included in subsequent analysis, and, as a result, data from $25 \%$ of the fibers were eliminated from subsequent analysis. Analysis of the different variables measured did not allow us to establish the origin of this variability.

Statistical analysis. Data throughout the text are expressed as mean \pm 1 SD. Grouped data were analyzed using two-tailed paired Student's $t$ test. The number of comparisons $(n)$ was minimized to include only critical time periods of interest, and the $P$ value required to achieve statistical significance was calculated as $0.05 / n$. Except where indicated, values at time periods analyzed were compared to control values.

Limitations of study. The experimental model used in these studies was designed to simulate some of the known effects of myocardial ischemia $(7,8)$. It is clear, however, that the conditions imposed in these experiments differ from true ischemia in several important respects. Superfusion of isolated tissue with modified electrolyte solutions containing reduced $\mathrm{PO}_{2}$ results in washout of many metabolites that would accumulate in a closed system such as amphiphiles, free radicals, purine nucleotides, and extracellular $\mathrm{K}^{+}(16,17)$. Secondly, the Purkinje fibers were not exposed to circulating catecholamines and free fatty acids (16). Thirdly, in myocardial ischemia due to coronary occlusion, Purkinje fibers are exposed to an unknown ionic environment as they continue to be bathed in intracavitary blood, despite the interruption of their perfusion after occlusion. Fourthly, the imposition of extracellular acidosis generates a steep inwardly directed proton gradient, which is directionally opposite to the outwardly directed proton gradient that occurs during ischemia. Nonetheless, the similarities between the electrophysiologic derangements reported in this study and in in vivo experiments in which reperfusion follows brief periods of occlusion suggest that important insights into ischemic dysfunction and reperfusion abnormalities can be obtained.

Measurement of extracellular $\mathrm{K}^{+}$activity only approximates the

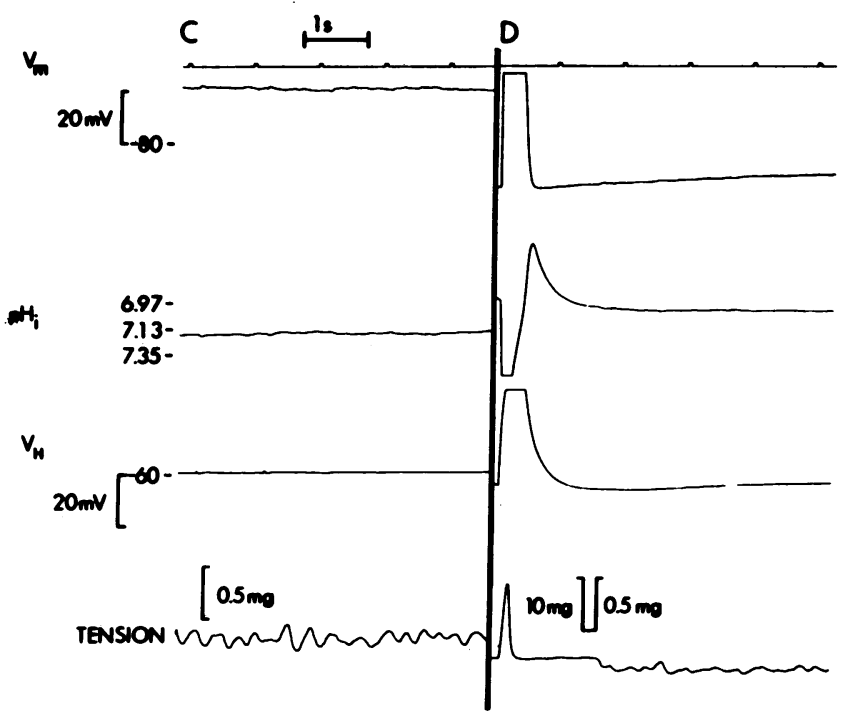

Tyrode's solution $(C)$, and $50 \mathrm{~min}$ after reexposure to control Tyrode's solution $(D)$. The low amplitude oscillations in transmembrane potential, along with the depolarization, and irregular oscillations in tension are most clearly noted in $C$. true value, as the electode tip undoubtedly distorted the true paracellular space, thereby altering the surface to volume ratio of the space, and probably impeded the passive diffusion of $\mathrm{K}^{+}$to and from the bulk solution. Nonetheless, as the rise in $\alpha_{\mathbf{k}}^{\mathrm{e}}$ after exposure to Tyrode's solution containing $8 \mathrm{mM} \mathrm{KCl}$ closely matched the predicted increment as previously shown (14) and verified in the present study, we believe the values of $\alpha_{\mathrm{K}}^{\mathrm{e}}$ reported can be viewed as reasonable estimates of the true value.

\section{Results}

Transmembrane potential changes. Under control conditions, the mean maximum diastolic potential $\left(E_{\mathrm{MDP}}\right)^{1}$ in 19 fibers was $-92.6 \pm 2.4 \mathrm{mV}$ (Fig. 1). The temporal course of the changes in $E_{\mathrm{MDP}}$ in response to exposure to solution II followed by return to control solution (solution I) is illustrated in Figs. 1 and 2. Superfusion with solution II led to a reduction in $E_{\mathrm{MDP}}$ in the initial $10 \mathrm{~min}$ to $-85.7 \pm 4.7 \mathrm{mV}(P<0.001)$. Thereafter, $E_{\mathrm{MDP}}$ changed little, so that at the end of $40 \mathrm{~min}$ a value of $-86.0 \pm 4.0 \mathrm{mV}$ was recorded, which was significantly lower than the control value $(P<0.001)$.

At the end of $40 \mathrm{~min}$ the fibers were reexposed to solution I. $E_{\mathrm{MDP}}$ rapidly hyperpolarized to $-90.0 \pm 4.7 \mathrm{mV}$ at $2 \mathrm{~min}$. The time to the peak of hyperpolarization ranged from 1 to 3 min, with its magnitude in a range of $2.0-13.0 \mathrm{mV}$ (mean $=7.6 \pm 2.3 \mathrm{mV}$ ). The period of hyperpolarization was then followed by rapid depolarization and loss of excitability. Depolarization began within $5 \mathrm{~min}$ of return to solution I, and inexcitability always occurred by $10 \mathrm{~min}$, lasting $20-50 \mathrm{~min}$. At $10 \mathrm{~min}, E_{\mathrm{MDP}}$ had depolarized to $-47.0 \pm 7.5 \mathrm{mV}(P$ $<0.001$ ), and thereafter gradual recovery of $E_{\mathrm{MDP}}$ and excitability occurred. After 1-h return to solution I, $E_{\mathrm{MDP}}$ had recovered to near control values $(P=\mathrm{NS})$. Early in the course of reexposure to solution I, small amplitude oscillatory potentials

1. Abbreviations used in this paper: MDP, maximum diastolic potential; RT, resting tension; TT, twitch tension. 

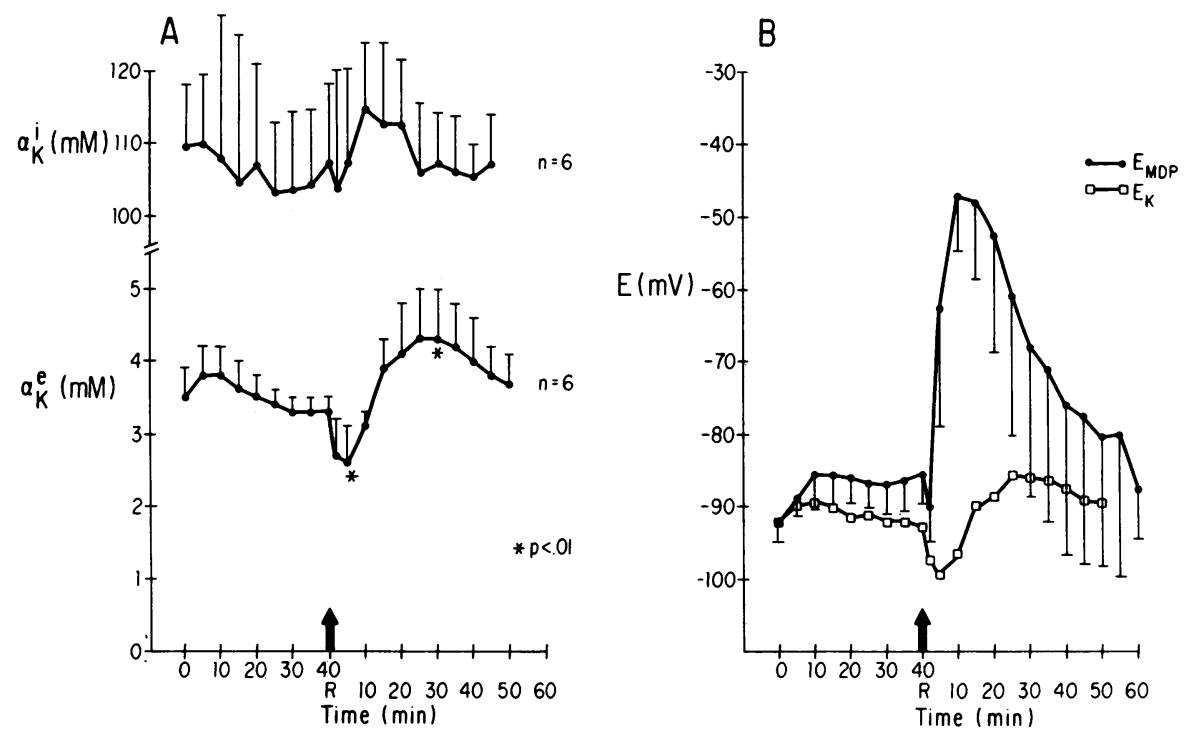

Figure 3. Time course of intracellular $\left(\alpha_{\mathrm{K}}^{\mathrm{i}}\right)$ and extracellular $\left(\alpha_{\mathrm{K}}^{\mathrm{e}}\right)$ potassium obtained from separate sets of experiments during exposure to $40 \mathrm{~min}$ of solution II and after return to solution $I(A) .(B)$ Comparison of maximum diastolic potential $\left(\bullet, E_{\mathrm{MDP}}\right)$ illustrated in Fig. 1 with the potassium equilibrium potential ( $\square$ $E_{\mathrm{K}}$ ) calculated from the values shown in $A$. were seen during diastole (Fig. 2); their amplitude progressively decreased during the 60 -min recovery period (Fig. 2, C and $D$ ). At no time did these potentials lead to triggered activity.

Intracellular and extracellular $K^{+}$activity, $E_{K}$. Intracellular $\mathrm{K}^{+}$activity was $109.5 \pm 8.7 \mathrm{mM}(n=6)$ under control conditions, and neither exposure to solution II nor return to control conditions was associated with any significant change in $\alpha_{\mathrm{K}}^{i}$ as compared to control values (Fig. $3 \mathrm{~A}$ ).

Extracellular $\mathrm{K}^{+}$activity was $3.5 \pm 0.4 \mathrm{mM}(n=6)$ under control conditions, and small changes during imposition and recovery from combined hypoxia-lactic acidosis were seen (Fig. $3 \mathrm{~A}$ ). Immediately after return to control Tyrode's solution, a small but significant transient fall in $\alpha_{\mathrm{K}}^{\mathrm{e}}$ was observed (2.6 $\pm 0.5 \mathrm{mM}, 5 \mathrm{~min}, P<0.03)$. Thereafter, $\alpha_{\mathrm{K}}^{\mathrm{e}}$ began to rise, reaching peak values of $4.3 \pm 0.7 \mathrm{mM}$ by $25 \mathrm{~min}$.

Because $\alpha_{\mathrm{K}}^{\mathrm{i}}$ and $\alpha_{\mathrm{K}}^{\mathrm{e}}$ were not measured simultaneously in the same preparations, $E_{\mathrm{K}}$ was calculated using the mean values at each time interval (Fig. $3 B$ ). Exposure to solution II resulted in a transient decline in $E_{\mathrm{K}}$ with a gradual return to control values at the end of this period. Upon return to solution I, $E_{\mathrm{K}}$ initially increased to $-99 \mathrm{mV}$ and then gradually declined to a minimum value of $-85.6 \mathrm{mV}$ at $25 \mathrm{~min}$. Although $E_{\mathrm{K}}$ approximated $E_{\mathrm{MDP}}$ under control conditions, the difference $\left(E_{\mathrm{MDP}}-E_{\mathrm{K}}\right)$ increased to $8.7 \mathrm{mV}$ at the end of exposure to solution II. Initially during recovery $E_{\mathrm{MDP}}-E_{\mathrm{K}}$ was 7.8 $\mathrm{mV}$ ( $2 \mathrm{~min}$ ) but increased dramatically to $48.9 \mathrm{mV}$ at $10 \mathrm{~min}$ when $E_{\mathrm{MDP}}$ was $-47.0 \mathrm{mV}$, and the preparations were still inexcitable.

Intracellular $\mathrm{Na}$ activity. The temporal course of the $\alpha_{\mathrm{Na}}^{\mathrm{i}}$ values during sequential exposure to solutions I and II is illustrated in Fig. 4. The mean control $\alpha_{\mathrm{Na}}^{\mathrm{i}}$ in 10 preparations was $8.7 \pm 1.3 \mathrm{mM}$ (Fig. 4). Superfusion with solution II caused $\alpha_{\mathrm{Na}}^{\mathrm{i}}$ to rise slowly to a maximum value of $10.9 \pm 1.9 \mathrm{mM}(P<0.01)$ at the end of this period. Upon return to control conditions, $\alpha_{\mathrm{Na}}^{\mathrm{i}}$ rapidly declined, reaching a minimum value of $5.1 \pm 2.2$ $\mathrm{mM}(P<0.01)$ at $10 \mathrm{~min}$. Thereafter, $\alpha_{\mathrm{Na}}^{\mathrm{i}}$ gradually returned to control values. To ascertain the role of the Na-K pump in the changes in $\alpha_{\mathrm{Na}}^{\mathrm{i}}$ recorded, acetylstrophanthidin (4-5 $\times 10^{-7}$ M) was added to solution II during the final 10-min of exposure, and now $\alpha_{\mathrm{Na}}^{\mathrm{i}}$ rose to $19.9 \pm 3.8 \mathrm{mM}$. After $5 \mathrm{~min}$ of reex- posure to solution I, $\alpha_{\mathrm{Na}}^{\mathrm{i}}$ was unchanged at $19.1 \pm 7.7 \mathrm{mM}$ and gradually fell to control values $(6.9 \pm 1.4 \mathrm{mM}$ at $25 \mathrm{~min})$. To ascertain the effect of lactic acidosis alone and reversal of $\mathrm{pH}$ gradient on $\alpha_{\mathrm{Na}}^{\mathrm{i}}$, the five fibers were exposed to solution IV; no significant change in $\alpha_{\mathrm{Na}}^{\mathrm{i}}$ was detected (Table II).

Intracellular $\mathrm{pH}$. The most profound changes in intracellular cation activity occurred with $\mathrm{H}^{+}$, as reflected by changes in $\mathrm{pH}_{\mathrm{i}}$ (Figs. 2 and 5). The $\mathrm{pH}_{\mathrm{i}}$ in eight preparations superfused with Tyrode's solution ( $\mathrm{pH} 7.38-7.42$ ) averaged 7.06 \pm 0.05 $\left(\alpha_{\mathrm{H}}^{\mathrm{i}}\right.$ of $\left.8.7 \times 10^{-8} \mathrm{M}\right)$. Exposure to solution II caused a rapid and steady decline in $\mathrm{pH}_{\mathrm{i}}$. Immediately before return to control Tyrode's solution, $\mathrm{pH}_{\mathrm{i}}$ averaged 6.49 $0.04(P<0.001)$. Return to solution I resulted in a rapid recovery and ultimately an alkaline overshoot in $\mathrm{pH}_{\mathrm{i}}$ to $7.14 \pm 0.07$ at $20 \mathrm{~min}$, followed by return to control values by $60 \mathrm{~min}$.

In nine preparations, hypoxia alone (solution III) resulted in a gradual but steady fall in $\mathrm{pH}_{\mathrm{i}}$ from $7.06 \pm 0.04$ to $6.91 \pm 0.07(P<0.001)$ (Fig. 5). When five preparations were superfused with acidotic Tyrode's solution (solution IV, $\mathrm{pH}_{0}$ $=6.79-6.82), \mathrm{pH}_{\mathrm{i}}$ reached a minimum of $6.88 \pm 0.07$ after 15 min and remained unchanged for the remainder of the exposure period. Neither the return to control conditions from

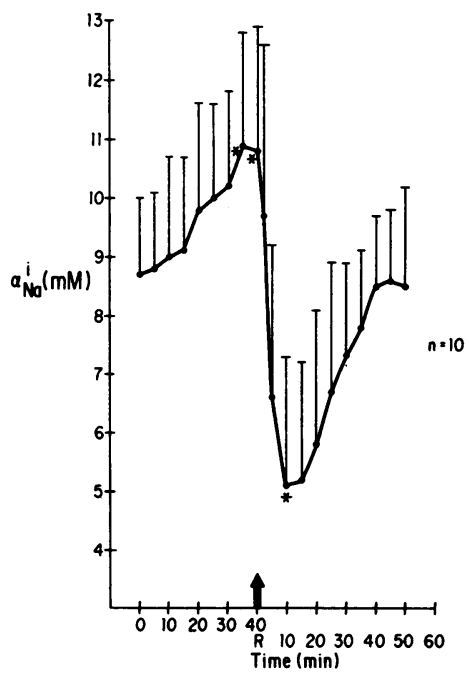

Figure 4. Time course of intracellular sodium activity $\left(\alpha{ }_{\mathrm{Na}}^{i}\right)$ during the 40 -min exposure to solution II and after return to control Tyrode's solution in 10 preparations. 
Table II. Intracellular Sodium Activity $\left(\alpha_{N a}^{i}\right)$ during Exposure to Control Tyrode's Solution (C) after 40-min Exposure to the Intervention Solutions (40 $\mathrm{min}$ ) and $5 \mathrm{~min}$ after Reexposure to Tyrode's Solution (Recovery: $5 \mathrm{~min}$ )

\begin{tabular}{lcccc}
\hline & & \multicolumn{3}{c}{$\alpha N_{\infty}$} \\
\cline { 3 - 5 } \multicolumn{1}{c}{ Intervention } & $n$ & $\mathrm{C}$ & $40 \mathrm{~min}$ & Recovery: $5 \mathrm{~min}$ \\
\hline & & & $\mathrm{mM}$ \\
& & & & \\
Solution II & 10 & $8.7 \pm 1.3$ & $10.9 \pm 1.9^{*}$ & $6.6 \pm 2.6$ \\
$\begin{array}{l}\text { Solution II } \\
\quad+\text { Strophanthidin }\end{array}$ & & & & \\
$\quad 4-5 \times 10^{-7}$ & 5 & $7.5 \pm 1.6$ & $19.9 \pm 3.8^{*}$ & $19.1 \pm 7.7$ \\
Solution IV & 5 & $9.5 \pm 0.9$ & $9.0 \pm 0.8$ & $8.3 \pm 1.2$ \\
\hline
\end{tabular}

${ }^{*} P<0.01$

hypoxia nor lactic acidosis alone resulted in the sequence of electrophysiologic events seen when combined (solution II).

To examine whether the electrophysiologic and mechanical changes observed after return to control state from combined hypoxia-lactic acidosis could be related to the rapid and marked changes in $\mathrm{pH}_{\mathrm{i}}$, seven preparations were exposed to Tyrode's solution V for 30 min (Fig. 6). Exposure of fibers to $\mathrm{pH}_{0}$ of 5.6-5.7 caused intracellular $\mathrm{pH}$ to fall from 7.06 \pm 0.03 to $6.52 \pm 0.11(P<0.001)$. Return to control conditions caused a rapid normalization and overshoot in $\mathrm{pH}_{\mathrm{i}}$ similar to that seen after recovery from solution II, but preparations did not exhibit a decrease in $E_{\text {MDP }}$ or a loss of excitability.

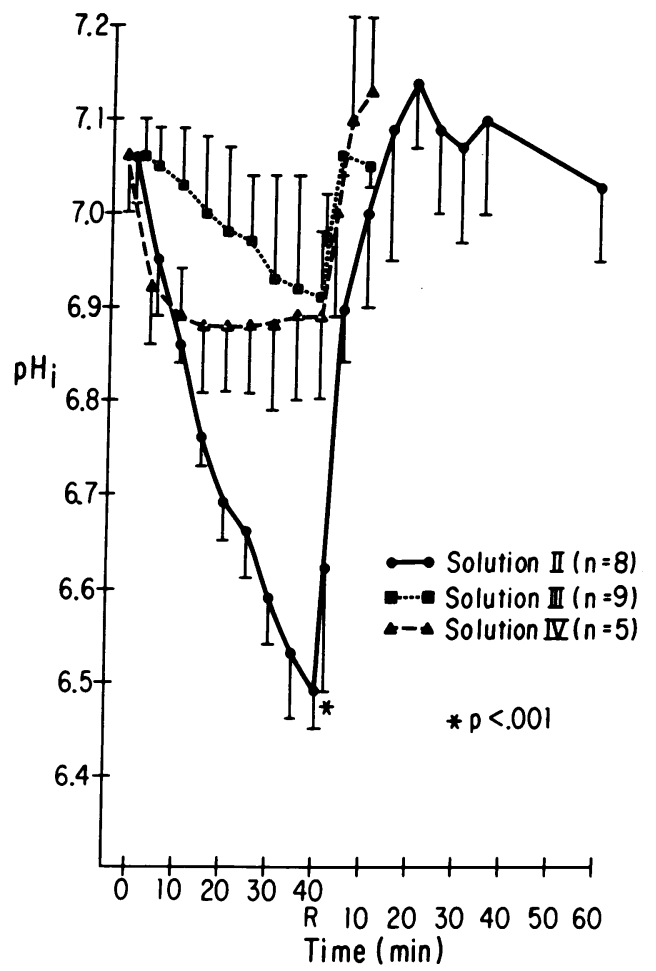

Figure 5. Time course of change of intracellular $\mathrm{pH}\left(\mathrm{pH}_{\mathrm{i}}\right)$ during 40 min exposure to combination of ischemia, hypoxia, glucose depletion, and lactic acidosis ( $\bullet$, solution II, $n=8$ ), hypoxia ( $n$, solution III, $n=9$ ), and lactic acidosis ( $\Delta$, solution IV, $n=5$ ) and after return to solution I.

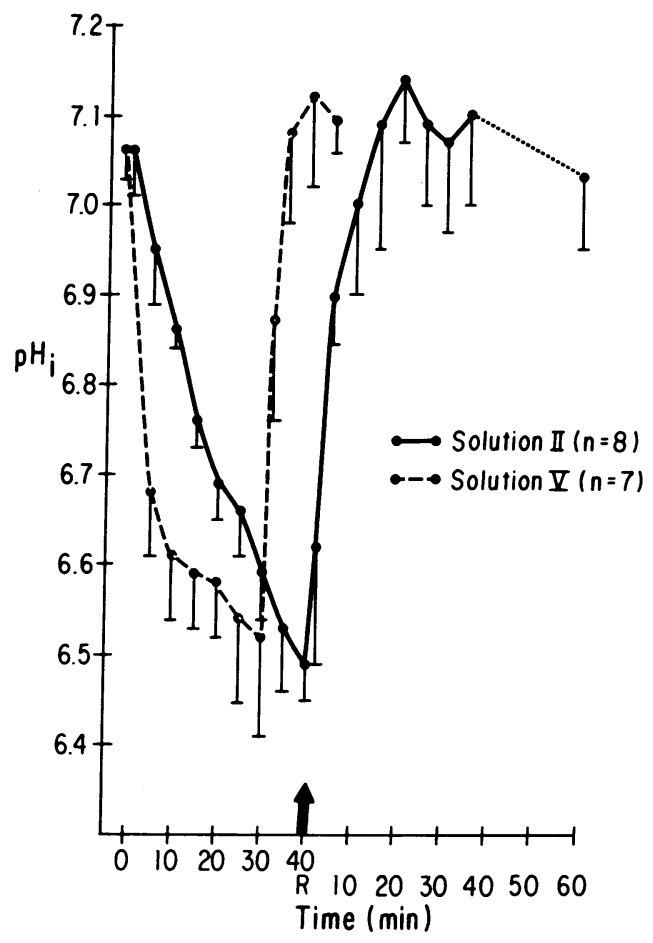

Figure 6. Time course of intracellular $\mathrm{pH}\left(\mathrm{pH}_{\mathrm{i}}\right)$ during exposure to combination of hypoxia, glucose depletion, and lactic acidosis $(\bullet-\bullet$, solution II, $n=8)$ and severe acidosis, $\mathrm{pH}_{0}=5.6-5.7$ $(\bullet---\bullet$, solution V, $n=7)$ and after return to solution I. Comparable degrees of intracellular acidification were achieved in two sets of experiments.

Resting and twitch tension. Because of the experimental system utilized, absolute values of resting tension (RT) were difficult to accurately quantitate. Therefore, we analyzed the relative change in resting tension corrected for cross-sectional area $\left(\mathrm{RT}_{\mathrm{c}}\right)$. Control values prior to exposure to combined hypoxia-lactic acidosis were designated as zero. Upon initial exposure to solution II, $R_{\mathrm{c}}$ rose slightly by $0.67 \pm 1.77 \mathrm{mg} / \mathrm{mm}^{2}$ and then declined steadily, but these fluctuations were not significant (Fig. 7). Upon return to control Tyrode's solution, there was a marked rise in $\mathrm{RT}_{\mathrm{c}}$ to a peak of $11.3 \pm 9.9 \mathrm{mg} / \mathrm{mm}^{2}$ ( $n=13, P<0.001$ ). Thereafter, $\mathrm{RT}_{\mathrm{c}}$ slowly declined but had not returned to control levels even after $50 \mathrm{~min}$. Early in the recovery period, oscillations in resting tension or aftercontractions were observed throughout diastole (Fig. 2). These aftercontractions progressively decreased in amplitude throughout the reperfusion period.

Twitch tension (TT) corrected for cross-sectional fiber area $\left(\mathrm{TT}_{\mathrm{c}}\right.$ ) fell from a mean control value of $6.4 \pm 5.5$ to $0.77 \pm 0.71$ $\mathrm{mg} / \mathrm{mm}^{2}(P<0.001)$ during the $40-\mathrm{min}$ of superfusion with solution I. When expressed as a percentage of control twitch tension, $\mathrm{TT}_{c}$ declined by $50 \%$ within $10 \mathrm{~min}$ of combined hypoxia-lactic acidosis. When $\mathrm{TT}_{\mathrm{c}}$ was examined as a function of $\mathrm{pH}_{\mathrm{i}}$, a steep relationship between $\mathrm{TT}_{\mathrm{c}}$ and $\mathrm{pH}_{\mathrm{i}}$ was observed; a $50 \%$ decline in $\mathrm{TT}_{\mathrm{c}}$ occurred at a time when $\mathrm{pH}_{\mathrm{i}}$ fell $0.20 \mathrm{U}$.

\section{Discussion}

The measurement of intracellular and extracellular cation activities along with electrical and mechanical properties has provided new insights into the electrophysiologic changes that 


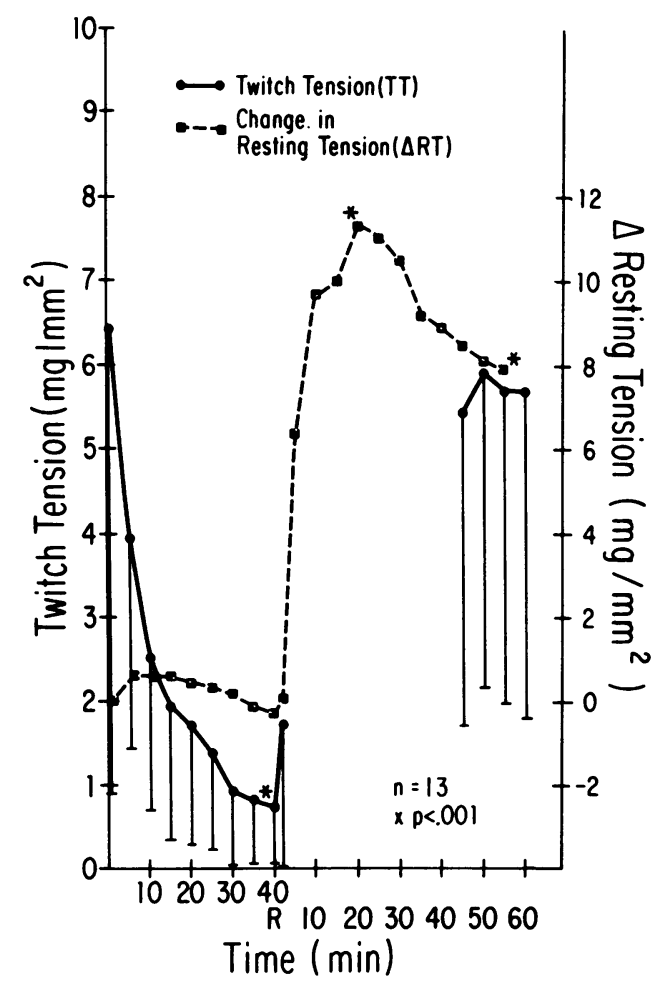

Figure 7. Time course for twitch tension ( $\bullet$ ) and change in resting tension ( $\square$ ) corrected for cross-sectional fiber area during the 40-min exposure to solution II and after return to solution I for up to $60 \mathrm{~min}$ in 13 preparations.

occur in this model of ischemia and reperfusion. The observations are best analyzed by arrangement into the following chronological phases: (1) exposure to the combination of hypoxia-lactic acidosis and glucose depletion (40 min), (2) initial (0-2 min), (3) early (2-10 min), and (4) late phases of reperfusion with control Tyrode's solution. The changes in $E_{\mathrm{MDP}}$, $\mathrm{pH}_{\mathrm{i}}$, tension, $\alpha_{\mathrm{Na}}^{\mathrm{i}}$, and $\alpha_{\mathrm{K}}^{\mathrm{e}}$ support the view that multiple ionic mechanisms underlie the electrophysiologic changes during the different phases of this model. Despite these gains, it is to be recognized that there are a number of limitations to this study, which are presented in Methods.

Changes in membrane potential, $\alpha_{K}^{i}$ and $\alpha_{K}^{e}$. $E_{\mathrm{MDP}}$ initially depolarized, reaching a plateau $10 \mathrm{~min}$ after the onset of superfusion with solution II. This initial depolarization, which occurred prior to a marked change in $\mathrm{pH}_{\mathrm{i}}$, is believed to result from an effect of $\mathrm{pH}_{0}$ upon outward $\mathrm{K}^{+}$current and/or inhibition of the Na-K pump (18). Our results suggest a small accumulation of $\mathrm{K}^{+}$in the extracellular space early during exposure to combined hypoxia-glucose depletion-lactic acidosis solution (solution II), indicating that $\mathrm{K}^{+}$efflux exceeds $\mathrm{K}$ uptake by the Na-K pump, which contributes to early reduction in $E_{\text {MDP }}$ but cannot explain its persistence as $\alpha_{\mathrm{K}}^{\mathrm{e}}$ falls later during exposure to solution II. Furthermore, exposure to acetylstrophanthidin late in the period of hypoxia-lactic acidosis caused a marked rise in $\alpha_{\mathrm{Na}}^{\mathrm{i}}$, indicating that inhibition of $\mathrm{Na}-\mathrm{K}$ ATPase activity by hypoxia-lactic acidosis is far from complete during exposure to solution II.

The changes in $E_{\mathrm{MDP}}$ after return to control perfusate are best considered in three phases. The initial hyperpolarization can be attributed to a decrease in $\alpha_{\mathrm{K}}^{\mathrm{e}}$, as $E_{\mathrm{MDP}}-E_{\mathrm{K}}$ was vir- tually unchanged before and immediately after reexposure to control Tyrode's solution. The subsequent marked decrease in $E_{\mathrm{MDP}}$ cannot be attributed to a redistribution of $\mathrm{K}^{+}$across the sarcolemma, as $E_{\mathrm{MDP}}-E_{\mathrm{K}}$ increased from 7.8 to $48.9 \mathrm{mV}$, but may be due, instead, to an increase in inward current. Two possible mechanisms to be considered are an increase in permeability to another cation via the transient inward current or an increase in electrogenic $\mathrm{Na}-\mathrm{Ca}$ exchange $(19,20)$. At the end of reperfusion, both $E_{\mathrm{MDP}}$ and $E_{\mathrm{MDP}}-E_{\mathrm{K}}$ had returned toward control values.

Changes in $\alpha_{\mathrm{Na}}^{i}$. We have shown a $25 \%(2.2 \mathrm{mM})$ rise in $\alpha_{\mathrm{Na}}^{\mathrm{i}}$ during $40 \mathrm{~min}$ of exposure to hypoxia, lactic acidosis, and glucose depletion. Similar findings were reported in guinea pig papillary muscles subjected to hypoxia, respiratory acidosis, and glucose-free solutions, albeit with a faster rise in $\alpha_{\mathrm{Na}}^{\mathrm{i}}$ noted (21). The rise in $\alpha_{\mathrm{Na}}^{i}$ seen in our study could be the result of reduced active efflux through inhibition of $\mathrm{Na}-\mathrm{K}$ ATPase activity secondary to hypoxia or acidosis $(22,23)$ or an increase in passive influx mediated by $\mathrm{Na}-\mathrm{Ca}$ exchange, $\mathrm{Na}-\mathrm{H}$ exchange, or a nonselective cation channel. While profound extra- and intracellular acidosis as documented in these experiments could inhibit the $\mathrm{Na}$ pump, the failure of $\alpha_{\mathrm{K}}^{\mathrm{e}}$ to rise in conjunction with the rise in $\alpha_{\mathrm{Na}}^{\mathrm{i}}$ and the ability of strophanthidin to cause a further marked increase in $\alpha_{\mathrm{Na}}^{i}$ immediately before the end of combined hypoxia-lactic acidosis indicates that Na-K ATPase inhibition, if present at all, is far from complete. Further, the $\mathrm{Na}-\mathrm{Ca}$ exchanger is unlikely to contribute to the rise in $\alpha_{\mathrm{Na}}^{\mathrm{i}}$, as it is inhibited by a fall in $\mathrm{pH}_{\mathrm{i}}$ which should lead to a decrease in $\mathrm{Na}$ influx via the $\mathrm{Na}-\mathrm{Ca}$ exchanger. Thus, in the absence of a significant increase in $\left[\mathrm{Ca}^{2+}\right]_{\mathrm{i}}$ it is difficult to attribute an increase in $\alpha_{\mathrm{Na}}^{\mathrm{i}}$ to the $\mathrm{Na}-\mathrm{Ca}$ exchanger. As a reduction in $\mathrm{pH}_{0}$ has been shown to cause a fall in $\alpha_{\mathrm{Na}}^{i}(24)$, the $\mathrm{Na}-\mathrm{H}$ exchanger is unlikely to contribute to $\mathrm{Na}$ influx early during exposure to solution II. However, as $\mathrm{pH}_{\mathrm{i}}$ continues to fall (Fig. 5), $\mathrm{Na}$ influx via the $\mathrm{Na}-\mathrm{H}$ exchanger would be expected to increase and contribute to the rise in $\alpha_{\mathrm{Na}}^{\mathrm{i}}$. Of considerable interest is the very rapid decline in $\alpha_{\mathrm{Na}}^{i}$ commencing almost immediately upon reintroduction of oxygen and normal $\mathrm{pH}$. This fall in $\alpha_{\mathrm{Na}}^{\mathrm{i}}$ begins simultaneously with the hyperpolarization of $E_{\mathrm{MDP}}$, fall in $\alpha_{\mathrm{K}}^{\mathrm{e}}$, and rapid increase in $\mathrm{pH}_{\mathrm{i}}$, pointing toward stimulation of $\mathrm{Na}-\mathrm{K}$ pump activity. Enhanced $\mathrm{Na}-\mathrm{K}$ pump activity is likely due to the reestablishment of aerobic metabolism, reduction in $\mathrm{P}_{\mathrm{i}}$ and rapid $\mathrm{pH}_{\mathrm{i}}$ recovery in the presence of an elevated $\alpha_{\mathrm{Na}}^{i}$. We attempted to test this hypothesis by adding acetylstrophanthidin (4-5 $\left.\times 10^{-7} \mathrm{M}\right)$ to the ischemic solution $10 \mathrm{~min}$ before reperfusion with control solution. While identification of the appropriate concentration that inhibited the $\mathrm{Na}$ pump yet did not irreversibly damage the fiber proved difficult, the concentration selected demonstrated that the fall in $\alpha_{\mathrm{Na}}^{i}$ during reperfusion was delayed. This observation in conjunction with the observed decline in $\alpha_{\mathrm{K}}^{\mathrm{e}}$ indicates that the early fall in $\alpha_{\mathrm{Na}}^{\mathrm{i}}$ during recovery was due to enhanced $\mathrm{Na}-\mathrm{K}$ pump activity.

While stimulation of the Na-K pump may contribute to the initial rapid fall in $\alpha_{\mathrm{Na}}^{\mathrm{i}}$, it does not adequately explain both the continued decline in $\alpha_{\mathrm{Na}}^{\mathrm{i}}$ below control values, as well as the nadir of $\alpha_{\mathrm{Na}}^{\mathrm{i}}$ occurring $5 \mathrm{~min}$ after the corresponding nadir for $\alpha_{\mathrm{K}}^{\mathrm{e}}$. Other contributing factors may include an increase in cell water, which dilutes sarcoplasmic $\mathrm{Na}$ content (2), an increase in $\mathrm{Na}-\mathrm{Ca}$ exchange, or a decrease in $\mathrm{Na}$ influx due both to a loss of excitability and to a loss of driving force resulting from membrane depolarization. If the changes were to be at- 
tributed solely to changes in cell volume or water, then an increase of nearly $100 \%$ would be required, and $\alpha_{\mathrm{k}}^{\mathrm{i}}$ should also have reflected this dilutional effect, but this was not observed. As the membrane begins its depolarization 2-5 min after recovery from the combination of hypoxia-lactic acidosis and glucose depletion, the rise in $\mathrm{pH}_{\mathrm{i}}$ would be expected to enhance the activity of the $\mathrm{Na}-\mathrm{Ca}$ exchanger (25). On the other hand, using our measurements of $V_{\mathrm{m}}$ and $\alpha_{\mathrm{Na}}^{i}$ to calculate the electrochemical driving force (assuming a stoichiometry of $3 \mathrm{Na}: 1 \mathrm{Ca}$ and equilibrium conditions) on the exchanger during the first $15 \mathrm{~min}$ of recovery, a fall in $\alpha_{\mathrm{Ca}}^{i}$ and thus $\mathrm{Na}$ influx is predicted. However, the absence of continuous measurements of $\alpha_{\mathrm{Ca}}^{\mathrm{i}}$ and the relative fluxes of $\mathrm{Na}$ and $\mathrm{Ca}$ through each of the transport pathways precludes an accurate estimation of the contribution of the $\mathrm{Na}-\mathrm{Ca}$ exchanger to the fall in $\alpha_{\mathrm{Na}}^{i}$.

Intracellular $\mathrm{pH}$. Control values of $\mathrm{pH}_{\mathrm{i}}$ were found to be similar to those reported by other investigators (26-28) and were higher than would be predicted from simple passive distribution resulting from the electrochemical gradient across the cell membrane. This transsarcolemmal proton gradient is maintained primarily by $\mathrm{Na}-\mathrm{H}$ exchange, although there remains some controversy regarding the relative importance of the $\mathrm{Cl}-\mathrm{HCO}_{3}$ transport mechanism (29). Hypoxia alone evokes a gradual but progressive and modest decline in $\mathrm{pH}_{\mathrm{i}}$ (Fig. 5), which likely results from lactate accumulation secondary to anaerobic glycolysis. The fall in $\mathrm{pH}_{\mathrm{i}}$ is modest, presumably due to lactate efflux and $\mathrm{H}^{+}$efflux via $\mathrm{Na} / \mathrm{H}$ exchange. In lactic acidosis alone $\left(\mathrm{pH}_{0}=6.79-6.82\right)$ there is a steeper rate of decline in $\mathrm{pH}_{\mathrm{i}}$ to 6.88 over the first $10 \mathrm{~min}$, presumably the result of an increased lactate burden imposed on the cell in addition to a decrease in $\mathrm{HCO}_{3}^{-}$buffering capacity in the perfusate. Thereafter, $\mathrm{pH}_{\mathrm{i}}$ stabilizes as equilibration with the perfusate has occurred. However, combination of hypoxia and lactic acidosis results in a progressive and steady decline in $\mathrm{pH}_{\mathrm{i}}$ to values lower than that resulting from a simple additive effect of each individual component of the model. While our experiments do not allow us to deduce whether a synergistic interaction of lactic acidosis and hypoxia upon intracellular pH occurred, experiments carried out on fatigued skeletal muscle bear on this question $(26,30,31)$. Total lactate efflux in skeletal muscle decreases, if the $\mathrm{pH}$ of the extracellular fluid is reduced. The decrease in lactate efflux has been attributed to the relatively higher membrane permeability to lactic acid over lactate ion and an inhibition of lactic acid dissociation and reduction in driving force for lactic acid extrusion as the $\mathrm{pH}$ of the extracellular fluid is reduced. The decreased outward movement of lactic acid will result in a relative increase in $\mathrm{H}^{+}$ in the cell. While the inclusion of lactate ions in solution II was intended to inhibit anerobic metabolism, the Purkinje fiber is a glycogen-rich preparation with a high glycolytic rate, and it is likely that under hypoxia-lactic acidosis conditions in our experiments glycolysis was not fully inhibited. Thus, the observed decline in $\mathrm{pH}_{\mathrm{i}}$ may simply be the result of continued lactate production via anaerobic metabolism coupled with a reduced lactate efflux, although breakdown of intracellular metabolites such as ATP may also contribute to the $\mathrm{pH}_{\mathbf{i}}$ decline (32).

Tension and $\alpha_{\mathrm{Ca}}^{i}$. Under physiologic conditions, the amount of sarcoplasmic free $\mathrm{Ca}^{2+}$ is reflected by resting and twitch tension, although the relationship is complex, and other factors such as $\mathrm{pH}_{\mathrm{i}}, \mathrm{ATP}$, and $\mathrm{P}_{\mathrm{i}}$ modulate myofilament sensitivity to free $\mathrm{Ca}^{2+}(33-35)$.
In this model, resting tension showed minimal change during combined hypoxia, acidosis, and glucose depletion, despite the fall in $\mathrm{pH}_{\mathrm{i}}$. This fall in $\mathrm{pH}_{\mathrm{i}}$ is known to decrease myofilament sensitivity to $\mathrm{Ca}^{2+}$, and it is therefore likely that $\alpha_{\mathrm{Ca}}^{i}$ rose during this period $(34,36)$, presumably reflecting $\mathrm{Ca}^{2+}$ displacement from internal buffering sites by $\mathrm{H}^{+}$(37). Twitch tension, which reflects the cyclic release and reuptake of $\mathrm{Ca}^{2+}$ by the sarcoplasmic reticulum, falls dramatically during hypoxia and/or lactic acidosis in this model. The simultaneous measurements of twitch tension and $\mathrm{pH}_{\mathrm{i}}$ during superfusion with solution II and solution $\mathrm{V}$ indicate that the accumulation of $\left[\mathrm{H}^{+}\right]_{\mathrm{i}}$ is not solely responsible for the observed negative inotropic effect during exposure to solution II. The change in $\mathrm{pH}_{\mathrm{i}}$ observed during a 59\% decrease in twitch tension after exposure to solution $\mathrm{V}$ was $0.38 \mathrm{U}$, while the same decline in twitch tension during exposure to solution II was associated with only a $0.28-\mathrm{U}$ change in $\mathrm{pH}_{\mathrm{i}}$. Similar results have been reported by Jacobus et al. (38). A greater pH sensitivity in mechanical activity during exposure to solution II is most likely due to inorganic phosphate accumulation that occurs during hypoxia secondary to $\mathrm{CrP}$ and ATP catabolism without resynthesis. Other investigators have shown $P_{i}$ to inhibit tension production in skinned cardiac muscle $(35,39)$ and in intact muscle (40). Thus, in this model, the observed negative inotropic effect of hypoxia, lactic acidosis, and glucose depletion on twitch tension is due to at least two factors affecting $\mathrm{Ca}^{2+}$ sensitivity of the myofilaments.

Upon recovery from hypoxia-lactic acidosis, there is a dramatic rise in resting tension. The extent to which this increase in tension reflects a marked rise in $\alpha_{\mathrm{Ca}}^{\mathrm{i}}$, as opposed to a reduction in the inhibitory effect of $\mathrm{P}_{i}$ and $\mathrm{H}_{i}^{+}$on the $\mathrm{Ca}^{2+}$ sensitivity of the myofilaments, will need to be ascertained by measurement of free calcium concentration $(26,41)$. Although it is likely that both mechanisms are involved, our observations support an increase in $\alpha_{\mathrm{Ca}}^{i}$ due to the appearance of oscillatory afterpotentials and aftercontractions during the onset of the recovery period. The increase in $\alpha_{\mathrm{Ca}}^{i}$ has been shown under experimental conditions to result in a transient inward current, which some have attributed to inward cation movement through a calcium-activated nonselective cation channel. In fact, two such channels have been identified and tentatively linked to the transient inward current $(42,43)$. Activation of such a channel early during the reperfusion phase could explain the dramatic depolarization and marked deviation of $E_{\mathrm{MDP}}$ from $E_{\mathrm{K}}$.

While the discussion thus far has focused on the potential mechanisms underlying the changes in $V_{\mathrm{m}}, \alpha_{\mathrm{Na}}^{\mathrm{i}}, \alpha_{\mathrm{K}}^{\mathrm{e}}, \mathrm{pH}$ tension, our data do not allow us to conclude which ionic translocation represents the primary derangement in this model. Indeed it is likely that a series of interrelated changes occur throughout both phases of this model. One might speculate that the elevation in $\alpha_{\mathrm{Na}}^{\mathrm{i}}$ at the end of the ischemic phase is a prime determinant of the changes that follow the onset of reperfusion. The rapid rise in $\mathrm{pH}_{\mathrm{i}}$ and washout of metabolites enable the $\mathrm{Na}-\mathrm{Ca}$ exchanger and $\mathrm{Na}-\mathrm{K}$ pump to respond to the elevated $\alpha_{\mathrm{Na}}^{i}$ and augment their activity to reduce $\alpha_{\mathrm{Na}}^{i}$ toward control values. It is difficult to determine the role that the exchanger plays in the reperfusion phase since the electrochemical gradient and fraction of total $\mathrm{Na}$ and $\mathrm{Ca}$ fluxes carried by it across the sarcolemma are unknown. However, we do not wish to imply that the exchanger could not play an important role in initiating intracellular $\mathrm{Ca}^{2+}$ overload during 
reperfusion. The dramatic increase in resting tension argue for an increase in myofilament sensitivity to calcium as $\mathrm{pH}_{\mathrm{i}}$ rises as well as a further increase in cytosolic calcium probably resulting from calcium release from the sarcoplasmic reticulum. The increase in intracellular free calcium concentration could in turn activate a nonselective cation channel, leading to an inward current and membrane depolarization. The magnitude of the $\alpha_{\mathrm{Na}}^{\mathrm{i}}$ increase during ischemia and the extent to which this increase is dissipated by the Na-K pump may very well help determine the degree of calcium loading during reperfusion and may explain the increased sensitivity of Purkinje fibers to acetylstrophanthidin.

In summary, we have shown that in this model of ischemia-reperfusion the late reduction in $E_{\mathrm{MDP}}$ during exposure to a perfusate simulating ischemia does not result from the redistribution of $\mathrm{K}^{+}$across the sarcolemma. After reexposure to control perfusate, the initial early hyperpolarization likely results from enhanced $\mathrm{Na}$ pump activity. The subsequent depolarization follows and parallels the dramatic rise in resting tension. The rise in resting tension suggests that free intracellular calcium increased, which should in turn activate the $\mathrm{Ca}^{2+}$-activated nonselective cation channel and result in a depolarizing current. The potential role that the $\mathrm{Na}-\mathrm{Ca}$ exchanger might play during reperfusion is discussed. Separation and quantification of the time course of these different ionic mechanisms awaits the outcome of future experiments.

\section{Acknowledgments}

We are very grateful to Dr. G. Ferrier for calling our attention to this model and to Dr. A. O. Grant for many helpful discussions and to C. Steenbergen for his critical review of the manuscript. We thank Dr. Joseph C. Greenfield, Jr. for continued support. We are also indebted to S. Webb and S. Muir for their helpful and tireless preparation of the manuscript.

This work was supported by grants HL-17670 and HL-19216 from the National Heart, Lung and Blood Institute and by Research Fellowship Grant 137 from the Ontario Heart and Stroke Foundation. Dr. Yee currently is a Career Scientist of the Ontario Ministry of Health.

\section{References}

1. Elharrar, V., and D. P. Zipes. 1977. Cardiac electrophysiologic alterations during myocardial ischemia. Am. J. Physiol. 233:H329H345.

2. Jennings, R. B., J. Schaper, M. L. Hill, C. Steenbergen, Jr., and K. A. Reimer. 1985. Effect of reperfusion late in the phase of reversible ischemic injury: changes in cell volume, electrolytes, metabolites, and ultrastructure. Circ. Res. 56:262-278.

3. Karagueuzian, H. S., J. J. Fenoglio, Jr., M. B. Weiss, and A. L. Wit. 1980. Coronary occlusion and reperfusion: effects on subendocardial cardiac fibers. Am. J. Physiol. 238:H581-H593.

4. Manning, A. S., and D. J. Hearse. 1984. Reperfusion-induced arrhythmias: mechanisms and prevention. J. Mol. Cell. Cardiol. 16:497-518.

5. Swain, J. L., R. L. Sabina, P. A. McHale, J. C. Greenfield, and E. W. Holmes. 1982. Prolonged myocardial nucleotide depletion after brief ischemia in the open-chest dog. Am. J. Physiol. 242:H818-H826.

6. Hill, J. L., and L. S. Gettes. 1980. Effect of acute coronary artery occlusion on local myocardial extracellular $\mathrm{K}^{+}$activity in swine. Circulation. 61:768-778.

7. Ferrier, G. R., M. P. Moffat, and A. Lukas. 1985. Possible mechanisms of ventricular arrhythmias elicited by ischemia followed by reperfusion: studies on isolated canine ventricular tissues. Circ. Res. 56:184-194.

8. Ferrier, G. R., M. P. Moffat, A. Lukas, and R. Mohabir. 1985. A model of ischemia and reperfusion: effect of potassium concentration on electrical and contractile responses of canine Purkinje tissue. In Cardiac Electrophysiology and Arrhythmias. D. P. Zipes and J. Jallife, editors. Grune \& Stratton, Orlando, FL. 325-330.

9. Ammann, D. F., F. Lanter, R. A. Steiner, P. Schulthess, Y. Shijo, and W. Simon. 1981. Neutral carrier based hydrogen ion selective microelectrode for extra- and intracellular studies. Anal. Chem. 53:2267-2269.

10. Guarnieri, T., and H. C. Strauss. 1981. Intracellular potassium activity in guinea pig papillary muscle during prolonged hypoxia. $J$. Clin. Invest. 69:435-442.

11. Lee, C. O., and M. Dagostino. 1982. Effect of strophanthidin on intracellular $\mathrm{Na}$ ion activity and twitch tension of constantly driven canine cardiac Purkinje fibers. Biophys. J. 40:185-198.

12. Sheu, S., and H. A. Fozzard. 1982. Transmembrane $\mathrm{Na}^{+}$and $\mathrm{Ca}^{2+}$ electrochemical gradients in cardiac muscle and their relationship to force development. J. Gen. Physiol. 80:325-351.

13. Kunze, D. L. 1977. Rate-dependent changes in extracellular potassium in the rabbit atrium. Circ. Res. 41:122-127.

14. Hill, J. A., J. L. Trantham, D. J. Browning, A. O. Grant, and H. C. Strauss. 1986. An upper limit for the electrogenic Na-K pump contribution to maximum diastolic potential in feline cardiac Purkinje fibers in steady state. Can. J. Physiol. Pharmacol. 64:641-648.

15. Lee, C. O. 1981. Ionic activities in cardiac muscle cells and application of ion-selective microelectrodes. Am. J. Physiol. 241:H459-H478.

16. Corr, P. B., R. W. Gross, and B. E. Sobel. 1984. Amphipathic metabolites and membrane dysfunction in ischemia myocardium. Circ. Res. 55:135-154.

17. Gettes, L. S. 1986. Effect of ischemia on cardiac electrophysiology. In The Heart and Cardiovascular System. H. A. Fozzard, R. B. Jennings, E. Haber, A. M. Katz, and H. Morgan, editors. Raven Press, New York. 1317-1341.

18. Lauer, M. R., B. F. Rusy, and L. D. Davis. $1984 . \mathrm{H}^{+}$-induced membrane depolarization in canine cardiac Purkinje fibers. Am. J. Physiol. 247:H312-H321.

19. Kass, R. S., W. J. Lederer, R. W. Tsien, and R. Weingart. 1978. Role of calcium ions in transient inward currents and aftercontractions induced by strophanthidin in cardiac Purkinje fibres. J. Physiol. (Lond.). 281:187-208.

20. Grinwald, P. M. 1982. Calcium uptake during post-ischemic reperfusion in the isolated rat heart: Influence of extracellular sodium. J. Mol. Cell. Cardiol. 14:359-365.

21. Wilde, A. A. M., and A. G. Kleber. 1986. The combined effects of hypoxia, high $\mathrm{K}^{+}$, and acidosis on the intracellular sodium activity and resting potential in guinea pig papillary muscle. Circ. Res. 58:249-256.

22. Balasubramanian, V., D. B. McNamara, J. N. Singh, and N. S. Dhalla. 1973. Biochemical basis of heart function. X. Reduction in the $\mathrm{Na}^{+}-\mathrm{K}^{+}$-stimulated ATPase activity in failing rat heart due to hypoxia. Can. J. Physiol. Pharmacol. 51:502-510.

23. Russell, J. M., W. F. Boron, and M. S. Brodwick. 1983. Intracellular $\mathrm{pH}$ and $\mathrm{Na}$ fluxes in barnacle muscle with evidence for reversal of the ionic mechanism of intracellular pH regulation. J. Gen. Physiol. 82:47-78.

24. Deitmer, J. W., and D. Ellis. 1980. Interactions between the regulation of the intracellular $\mathrm{pH}$ and sodium activity of sheep cardiac Purkinje fibres. J. Physiol. (Lond.). 304:471-488.

25. Philipson, K. D., M. M. Bersohn, and A. Y. Nishimoto. 1982. Effects of $\mathrm{pH}$ on $\mathrm{Na}^{+}-\mathrm{Ca}^{2+}$ exchange in canine cardiac sarcolemmal vesicles. Circ. Res. 50:287-293.

26. Roos, A., and W. F. Boron. 1981. Intracellular pH. Physiol. Rev. 61:296-434.

27. de Hemptinne, A. 1980. Intracellular $\mathrm{pH}$ and surface $\mathrm{pH}$ in 
skeletal and cardiac muscle measured with a double-barrelled pH microelectrode. Pfluegers Arch. Eur. J. Physiol. 386:121-126.

28. Ellis, D., and R. C. Thomas. 1976. Direct measurement of the intracellular $\mathrm{pH}$ of mammalian cardiac muscle. J. Physiol. (Lond.). 262:755-771.

29. Vaughan-Jones, R. D. 1982. Intracellular pH: its measurement, regulation, and utilization in cellular functions. Kroc Found. Ser. 15:239-252.

30. Kleber, A. G. 1984. Extracellular potassium accumulation in acute myocardial ischemia (editorial). J. Mol. Cell. Cardiol. 16:389394.

31. Mainwood, G. W., and G. E. Lucier. 1972. Fatigue and recovery in isolated frog sartorius muscles: The effects of bicarbonate concentration and associated potassium loss. Can. J. Physiol. Pharmacol. 50:132-142.

32. Hoerter, J. A., M. V. Miceli, D. G. Renlund, W. E. Jacobus, G. Gerstenblith, and E. G. Lakatta. 1986. A phosphorus-31 nuclear magnetic resonance study of the metabolic, contractile, and ionic consequences of induced calcium alterations in the isovolumic rat heart. Circ. Res. 58:539-551.

33. Couper, G. S., J. Weiss, B. Hiltbrand, and K. I. Shine. 1984. Extracellular $\mathrm{pH}$ and tension during ischemia in the isolated rabbit ventricle. Am. J. Physiol. 247:H916-H927.

34. Fabiato, A., and F. Fabiato. 1978. Effects of pH on the myofilaments and the sarcoplasmic reticulum of skinned cells from cardiac and skeletal muscles. J. Physiol. (Lond.). 276:233-255.

35. Kentish, J. C. 1986. The effects of inorganic phosphate and creatine phosphate on force production in skinned muscles from rat ventricle. J. Physiol. (Lond.). 370:585-604.
36. Blanchard, E. M., B. S. Pan, and R. J. Solaro. 1984. The effect of acidic $\mathrm{pH}$ on the ATPase activity and troponin $\mathrm{Ca}^{2+}$ binding of rabbit skeletal myofilaments. J. Biol. Chem. 259:3181-3186.

37. Langer, G. A. 1985. The effect of $\mathrm{pH}$ on cellular and membrane calcium binding and contraction of myocardium. Circ. Res. 57:374382.

38. Jacobus, W. E., I. H. Pores, S. K. Lucas, M. L. Weisfeldt, and J. T. Flaherty. 1982. Intracellular acidosis and contractility in the normal and ischemic heart as examined by PNMR. J. Mol. Cell. Cardiol. 14(Suppl. 3):13-20.

39. Herzig, J. W., J. W. Peterson, J. C. Ruegg, and R. J. Solaro. 1981. Vanadate and phosphate ions reduce tension and increase cross-bridge kinetics in chemically skinned heart muscle. Biochim. Biophys. Acta. 672:181-186.

40. Kusuoka, H., M. L. Weisfeldt, J. L. Zweier, W. E. Jacobus, E. Marban. 1986. Mechanism of early contractile failure during hypoxia in intact ferret heart: Evidence for modulation of maximal $\mathrm{Ca}^{2+}$-activated force by inorganic phosphate. Circ. Res. 59:270-282.

41. Kusoka, H., J. K. Porterfield, Weisman, H. F., Weisfeldt, M. L., and Marban, E. 1987. Pathophysiology and pathogenesis of stunned myocardium. Depressed $\mathrm{Ca}^{2+}$ activation of contraction as a consequence of reperfusion-induced cellular calcium overload in ferret hearts. J. Clin. Invest. 79:950-961.

42. Colquhoun D., E. Neher, H. Reuter, C. F. Stevens. 1981. Inward current channels activated by intracellular $\mathrm{Ca}$ in cultured cardiac cells. Nature (Lond.). 294:752-754.

43. Hill, J. A., R. Coronado, and H. C. Strauss. 1988. Reconstitution and characterization of a calcium-activated channel from heart. Circ. Res. 62:411-415. 